\title{
The Effects of Mitigation Measures on Flood Damage Prevention in Korea
}

\author{
Cheol-Hee Son, Jong-In Baek, Yong-Un Ban ${ }^{*, \dagger}$ and Sung-Ryong Ha ${ }^{*}+$ \\ Received: 2 October 2015; Accepted: 10 December 2015; Published: 21 December 2015 \\ Academic Editor: Fausto Cavallaro \\ Department of Urban Engineering, Chungbuk National University, Cheongju 28644, Korea; \\ chuleeson@chungbuk.ac.kr (C.-H.S.); yahoback@chungbuk.ac.kr (J.-I.B.) \\ * Correspondence: byubyu@chungbuk.ac.kr (Y.-U.B.); simplet@chungbuk.ac.kr (S.-R.H.) \\ + These authors contributed equally to this work.
}

\begin{abstract}
This study analyzed the characteristics of flood damages and the effects of structural and non-structural flood damage mitigation measures in Korea. First, a theoretical discussion of the structural and non-structural measures to mitigate flood damages was used to select the variables and devise the hypotheses. An analysis was conducted using the Auto-Regressive Integrated Moving-Average (ARIMA) time series methodology, Korean socioeconomic data, and damage characteristics of major flood events. The effects of flood damage mitigation measures on the extent of flood damages were assessed using an intervention time series model. The major findings were that the intervention effects of structural and non-structural measures were statistically significant from 1958 to 2013 (a period of 55 years) and that while the former were ineffective at mitigating flood damages, the latter were successful in doing so. Based on the above findings, policy suggestions for future flood damage mitigation measures in Korea were offered. For structural measures, the government should manage its existing facilities, recover ecosystems of damaged rivers, and devise mitigation measures for urban areas. For non-structural measures, the government should enhance its flood forecasting capacity, revise laws related to flood control and prevention, and update and rationalize land-use plans.
\end{abstract}

Keywords: flood damage mitigation measures; flood damage prevention; intervention time series

\section{Introduction}

Global warming has affected Korea by contributing to increased localized heavy rainfall, leading to floods and resulting in substantial and repetitive damages [1]. Floods have been a key concern in Korea's water resources policy, since they not only cause material damages but also cause significant loss of life [2]. Therefore, the government implements structural and non-structural flood damage prevention policies to reduce flood damages.

Structural and non-structural measures have been implemented to cope with the resultant flood damages [3]. Structural measures are strategies to control floods using a variety of structures, such as seawalls, dams, levees, and channels. Non-structural measures, as their name suggests, are not built, and they include directing land use away from hazardous areas, flood risk mapping, educating citizens by disseminating information on floods and flood-risk areas, protecting sensitive areas, using early warning systems, undertaking risk communication and sensitization, and devising and managing insurance arrangements $[4,5]$. Structural measures to prevent flood damage are based on estimations of predicted damages, and their effectiveness can be quantitatively determined. However, these measures are rarely cost effective and may modify the environment around them. On the other hand, while non-structural measures are relatively more economical and cost effective over the long term, it is difficult to analyze their preventive effects. 
Thus, there is a need to determine how these structural and non-structural measures can be applied to produce the desired effects. To do so, first, the effects of the structural and non-structural measures on flood damage prevention should be verified reliably. We examine the rational basis of numerous studies that used structural and non-structural measures as data sources for flood risk analysis, to appraise the respective flood prevention policies and assess the costs of flood risk management.

Some studies on structural mitigation measures have estimated the amount of flood damages from existing structural defenses. Lung-Sheng et al. [6] evaluated the efficacy of three types of structural measures proposed for flood damage prevention by using hydrological analysis and hydraulic routings. Ahn [7] simulated alternative solutions to structural measures used during flood drainage and analyzed the efficacy of flood mitigation measures. However, non-structural measures were limited to production of a flood inundation map and a qualitative assessment of its effectiveness. Poussin et al. [8] estimated the effect of structural measures on reducing flood damage, as well as cost effectiveness for homes, through a survey conducted in three sample regions in France. Some structural measures were shown to diminish flood damage but it was suggested that damage differs depending on regional characteristics.

Studies on non-structural measures include Schröter et al. [9], who used survey data to quantify the damage mitigation effects of flood forecasting and warning time. Faisal et al. [10] performed on-site investigations and interviews of residents in areas damaged by the 1988 flood. Other studies have analyzed the effects of education on flood damages management. Manoloche [11] cited US data indicating that high quality delivery of education, planning, and response resulted in a 70 percent reduction in insured damages over a 10-year period for commercial premises. Assuming a business-as-usual scenario, Somek [12] suggested that the flood risk strategies including community education in Victoria, Canada, could reduce the potential for flood risk in the next 50 years from CAD 745.5 million to CAD 410.6 million.

Other studies have considered not only structural and non-structural measures but also the social, economic, and environmental factors that cause flood damage. Jonkman et al. [13] analyzed the direct and indirect effects of flood damage control efforts through a framework that integrates economic, political, social, and psychological damage factors. Naturally, data on structural measures was also included in these studies. Dawson and Hall [14] conducted a simulation risk analysis of climate change, shoreline management, and socioeconomic scenarios along the coast of England. Van Stokkom et al. [15] investigated flood mitigation scenarios that account for climate change and the vulnerability of the floodplain area in the Netherlands. dos Santos and Tavares [16] tries to prioritize flood risk management strategies based on territorial (physical, demographic and socioeconomic data) and damage data, differentiating three contiguous watersheds. In conclusion, these studies showed that, among the many factors contributing to flood damage, socioeconomic factors are extremely important. In a study looking at the influence of geological factors, Gutiérrez et al. [17] proposed that karst landscapes are particularly susceptible to natural disasters, including floods. Furthermore, development and land use that does not take this into account will lead to further destruction of the karst landscape and ultimately worsen any damage caused by natural disasters.

Thus, all the previous studies focused on quantitative and policy implications of flood mitigation measures. However, some of these studies suffer certain limitations. First, while some researchers used appropriate methods to assess the effects of structural measures, the ability of the data to provide comprehensive results is restricted, because the data did not cover important geophysical, social, and economic characteristics. In other words, the geophysical, social, and economic variables employed in these studies did not consider regional variations. In general, such data are difficult to obtain, and as such, they cannot be used to construct indexes. Thus, proxy indexes have been used to generalize the results. Second, it is difficult to verify the effects of non-structural measures because of analytical or design limitations, such as heavy reliance on surveys, the analytical hierarchy process, and/or fragmentary comparative analysis. Third, the existing studies do not implement an analysis of actual 
proof of flood damage mitigation measures in long-term. There is therefore a need for analytical methods that not only address different aspects of flood damages but also accomplish this with high reliability. Therefore, the objectives of this study are to empirically analyze the characteristics of flood damages in Korea and the effects of flood damage prevention measures employed in the country, both structural and non-structural, on the extent of flood damages.

\section{Experimental Method}

This study comprises three steps: (1) development of the research design; (2) analysis of flood damage characteristics in Korea; and (3) analysis of the effects of mitigation measures on flood damage prevention. The first step involves a theoretical appraisal of the structural and non-structural measures for flood damage mitigation in Korea. Thereafter, hypotheses are devised to determine the prevention effects and choose the measurable and applicable variables. Then, relevant data are collected for the analysis. By considering major flood events, the second step examines the characteristics of flood damages in Korea, using a qualitative analysis of spatial and temporal changes and trends in social and environmental conditions, including precipitation. The third step analyzes the effects of flood damage mitigation prevention measures using an intervention time series model. The presentation of the analytical results is followed by a discussion of the policy significance of the results.

\subsection{Research Design}

The study area covers the entire territory of the Republic of Korea. Korea is a peninsula and the total land area including its islands measures $12,833 \mathrm{~km}^{2}$. Over 70 percent of the land is mountainous [18]. Mountains with an altitude of more than $1000 \mathrm{~m}$ above sea level are located in the eastern part, while urban settlements are prominent in the western part, which consists of low and flat hilly plains (see Figure 1). Korea is home to 4 rivers-the Han, Nakdong, Geum and Yeongsan-which give rise to 14 major tributaries. The rivers are highly prone to flooding because of their short water course extensions and steep slopes in the mountainous areas. The thin soil cover and low moisture-containing capacity cause frequent weathering and erosion during and after heavy rain. The resulting soil runoff accelerates flood damages. The country's capital houses $24,988,368$ people, nearly half of the Korean population (49.25 percent) [19] (see Figure 1). In total, 3,407,417 people live in such flood-risk areas (the phrase "flood-risk areas" include "areas prone to flood' and 'natural hazard zone") (7.2 percent of the national population) and among them, 1,023,344 that are aged under 14 or over 65, classed as vulnerable, equaling 2.16 percent of the national population (see Figure 2).

To analyze the effects of mitigation measures on flood damage prevention in Korea, it is necessary to understand the current policies related to floods. Korea's flood damage prevention mitigation measures can be summarized as follows. Structural measures, including large-scale river management and flood control projects, have been conducted annually and consistently since 1964, in compliance with the amendments to the River Act and the Comprehensive National Development Plan, and the terms of the loans secured from the Asian Development Bank. Some of the structural river management and flood control measures have taken the form of embankment and dam construction projects, the effects of which have been experienced since 1965. Regarding the non-structural measures, as of the mid-2010s, most of them (except for prior evacuation plans) continue to be in their early stages of development, and are, therefore, considered insufficient at this time. Prior evacuation plans aimed at protecting human lives have been in place since the 1990s, with their positive effects bearing fruit since 1991, particularly after computerized weather forecasts became possible. These technologies include the Masscomp System (Massachusetts Computer Corporation), which was implemented in 1990, and the personal computer communications network, which was established in 1991 in Korea. 


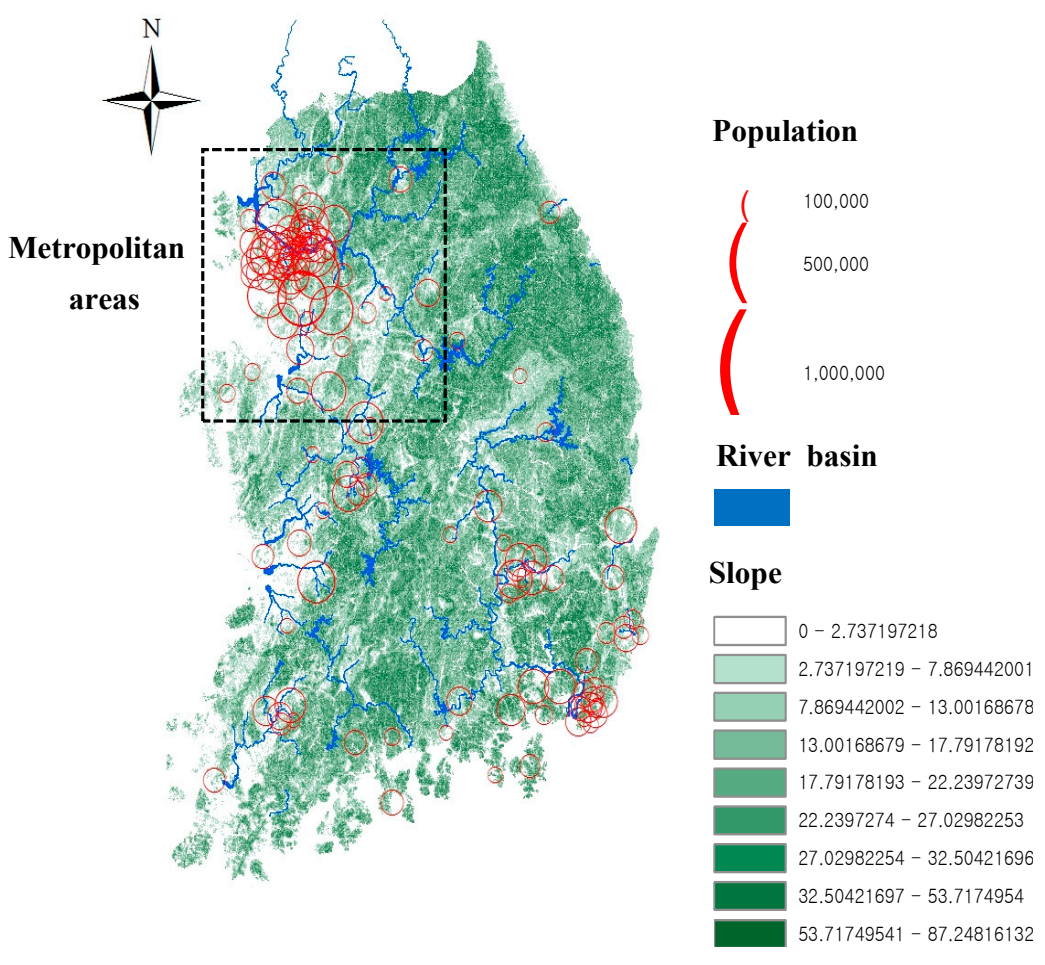

Figure 1. Korea's mountains and urban size.

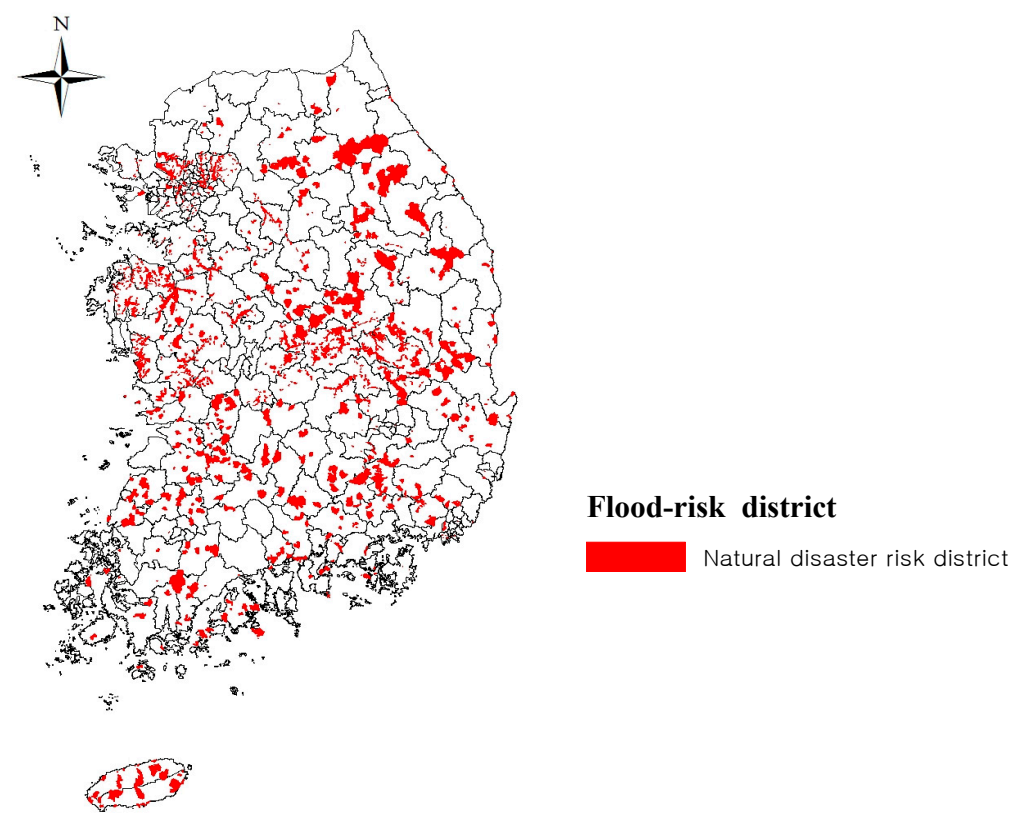

Figure 2. Korea's flood-risk areas (source: [20]).

Two questions emerge from this review of flood damage prevention mitigation measures. First, how have damages from floods in Korea changed? This question suggests the need to analyze the characteristics of flood damages across time and space. Second, are the current flood damage prevention mitigation measures effective? This question implies that there is a need to empirically analyze the effects of social, economic, and environmental factors on flood damages. To address 
the effects of flood damage prevention mitigation measures in Korea, the following general research hypothesis is devised: Structural and non-structural flood damage mitigation measures in Korea influence flood damage prevention.

The study area spans the entire territory of the Republic of Korea. The data employed in the study relevant to flood damages include data on damages to human lives (fatalities and missing persons), sizes of the flood-affected areas (ha), and the extent (amount) of damage to (1) buildings, (2) farmland, (3) ships, (4) crops, and (5) and public facilities, and other damages. Importantly, data on the monetary extent of damages are not suitable for time series analysis because such amounts are estimated at once, as opposed to considering the increase in the actual and asset values over time. In other words, the monetary value of damages is closely related to the growth of the national economy. Meanwhile, by considering flood damage mitigation measures, Korea deducts that River management and flood control have been implemented as a structural manner and Prior evacuation plans have been practiced as a non-structural measures. On the basis of these, we referred to the studies on the flood-affected area governed by River management [21] and flood control, and an early warning system is efficient in reduction of damages to human life as the reason to use variables [22]. Therefore, this study uses the data on damages to human life and flood-affected areas to analyze the effects of the policies relevant to each non-structural and structural measure, respectively. Additional data are collected from the Annual Disaster Statistical Review [20], which is published by the government, and the Water Resources Management Information System from 1958 to 2013 (amounting to a considerable period of 55 years). The specific hypotheses addressed by these data are as follows.

$H 1$ = River management and flood control in Korea, which began in 1964, resulted in effects attributable to structural measures after 1965.

$H 2$ = Prior evacuation plans in Korea, which were first implemented in 1991, resulted in effects attributable to non-structural measures after 1991.

\subsection{Analyzing Flood Damage Characteristics}

With respect to flooding, the social and economic environments and precipitation have a significant influence on material damages and damages to human life, and they are the key factors determining flood size and temporal-spatial distribution. Because the frequency of flood events and the extent of the resultant damages vary across space and time, it is necessary to analyze the relevance of socioeconomic indexes to flood damages and the manner in which changes in precipitation quantitatively relate to floods that cause major damages. The major flood events in Korea are selected based on several aspects. The period of the case study was from 1960 to 2010 and results were divided into urban and non-urban areas. This research aims to draw time and spatial features from macroscopic perspectives. The factors included in this analysis are shown in Table 1.

Table 1. Methodology for analyzing flood damage characteristics.

\begin{tabular}{|c|c|}
\hline $\begin{array}{l}\text { Flood Damage } \\
\text { Characteristic }\end{array}$ & Factors \\
\hline $\begin{array}{l}\text { Socioeconomic } \\
\text { status and trends }\end{array}$ & $\begin{array}{l}\text { Population, Gross Domestic Product (GDP), urbanization rate, } \\
\text { index of aging }\end{array}$ \\
\hline $\begin{array}{l}\text { Precipitation status } \\
\text { and trends }\end{array}$ & $\begin{array}{l}\text { Period of precipitation, and magnitude and frequency of } \\
\text { extreme precipitation }\end{array}$ \\
\hline $\begin{array}{l}\text { Events and extent } \\
\text { of flood damages }\end{array}$ & $\begin{array}{l}\text { Period of damage, areas affected, details of damage, nature of damage } \\
\text { Causes of flooding } \\
\text { Temporal characteristics } \\
\text { Spatial characteristics (urban and non-urban areas, as classified by } \\
\text { National Land Planning and Utilization Act, 2015) }\end{array}$ \\
\hline
\end{tabular}




\subsection{Analyzing the Effects of Flood Damage Prevention Mitigation Measures}

This study quantitatively analyzes the effects of flood damage prevention measures using the Auto-Regressive Integrated Moving Average (ARIMA) time series methodology. This analysis is used to construct the model and test the hypotheses while employing the time series data. It helps to determine trends and predict the future [23]. This method uses external events as independent variables and is useful to assess whether those events actually influenced the outcome variable when the timing of the intervention and cause are known and for estimating the effects of the same.

The ARIMA model consists of $\mathrm{p}$ past factors (auto-regressive factors) and q confounding factors (moving average factors) with $\theta_{0}$, which represents the integrated elements. Therefore, it is expressed as $\operatorname{ARIMA}(p, d, q)$, where $p=$ autoregressive factor, $q=$ moving average factor, and $d=$ difference.

The ARIMA model can be expressed by Equation (1):

$$
Y_{t}=\theta_{0}+\sum_{i=1}^{k} \varnothing_{i}(B) X_{i, t}+\frac{\theta(B)}{\varnothing(B)} a t
$$

where $t$ refers to time; $B$ denotes the backward shift operator, that is, $B X_{t}=X_{t}-1 ; Y_{t}$ refers to the raw data, $\theta_{0}$ is a constant, $\varnothing(B)$ is the autoregressive value, and $\theta(B)$ denotes the average values of movement.

The intervention time series model assumes that if time series $Y_{t}$ with no intervention follows the ARIMA $(p, d, q)$ model, external shock has an additive effect. This probability model represents the structural changes in the time series data when it reaches a new state after an intervention from the stable state or when it cannot reach a balanced state after the intervention. This notion can be expressed as Equation (2).

$$
Y_{t}=\frac{\omega(B) B^{b}}{\delta(B)} I_{i}^{(T)}+\frac{\theta(B)}{\varnothing(B)} a_{t}
$$

where, $\varnothing(B) / \theta(B) a_{t}$ is the estimated ARIMA $(p, d, q)$ model, and $\omega(B) B^{b} / \delta(B)$ represents the intervening variables. $B$ refers to the delay time of intervention effects, $\omega(B)$ denotes the expected effects of early intervention, $\delta(B)$ refers to the persistent effects of the intervention, and $I_{t}$ refers to the intervening variables. The intervening variables take two forms, pulse function and step function, according to the duration of a certain event. The pulse function, $P_{t}^{(T)}$, is used when a given event occurs at a point in $t$ and its effect influences only that point (defined in Equation (3)). The step function, $S_{t}{ }^{(T)}$, is used when a certain event occurs at a point in $t$ and its effect has a continuous influence even after the point of occurrence, as shown in Equation (4).

$$
\begin{aligned}
& P_{t}^{(T)}=\left\{\begin{array}{l}
0, t \neq T \\
1, t=T
\end{array}\right. \\
& S_{t}^{(T)}=\left\{\begin{array}{l}
0, t<T \\
1, t \geqslant T
\end{array}\right.
\end{aligned}
$$

The assessment of the transfer function model is similar to the procedure for the ARIMA model. For estimation and verification of the intervention time series model, statistics are repeated throughout the process of identifying, estimating, and diagnosing the model that reflects the intervening variable, $\omega(B) B^{b} / \delta(B)$, after estimating and diagnosing the ARIMA model, $\varphi(B) / \theta(B) a_{t}$. This method was developed by Box and Jenkins [23] (see Figure 3). 


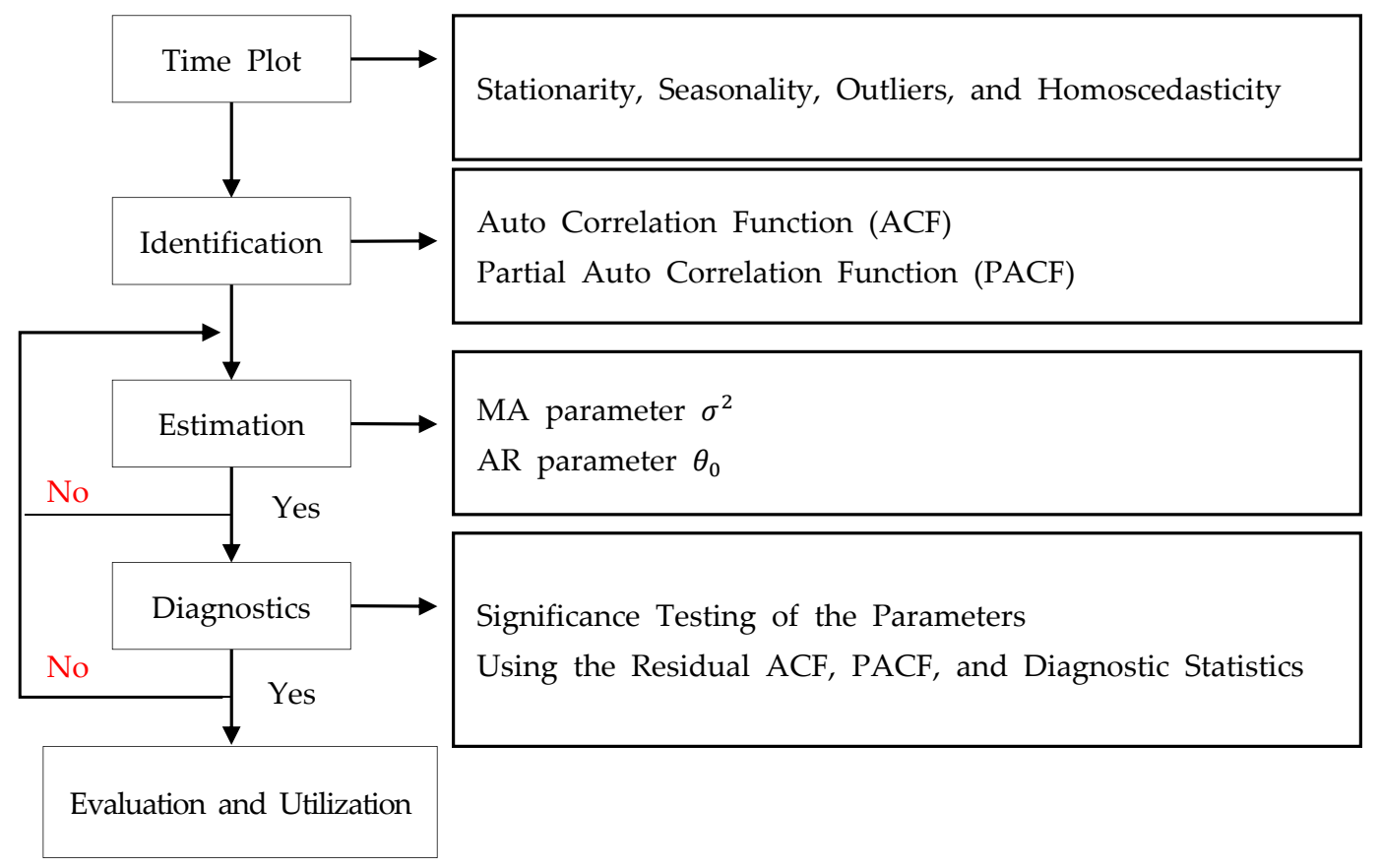

Figure 3. Model development (Source: [23]).

\section{Results}

\subsection{Characteristics of Flood Damages in Korea}

The characteristics of flood damages in Korea are interesting. First, the economy grew rapidly after 1960 in response to improved national economic development, loans from the Asian Development Bank in 1972, and the hosting of the 1988 Seoul Olympics. The values of land and buildings increased, thus raising the monetary amount of flood damages. Further, because the population is rapidly aging, the proportion of the population vulnerable to the effects of floods is also increasing (see Figure 4).

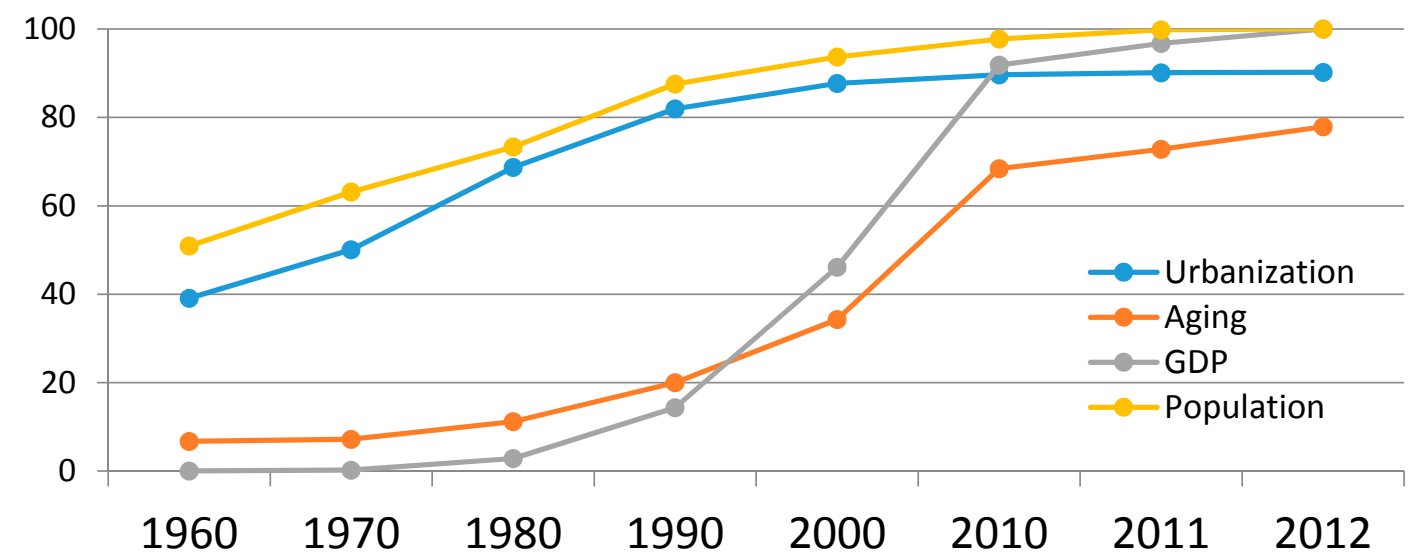

Figure 4. Social and economic status and trends (percent), 1960-2012 (Source: [19]).

Secondly, damages caused by floods tend to be concentrated from June to September (see Figure 5). The average hourly rainfall in Korea was $15-20 \mathrm{~mm}$ in the $1970 \mathrm{~s}, 30-31 \mathrm{~mm}$ in the $1980 \mathrm{~s}, 31-39 \mathrm{~mm}$ in the 1990s, and $39-45 \mathrm{~mm}$ in the 2000s. Thus, the increase in average hourly rainfall over a short period is quite apparent, and this rise has significantly influenced the extent of flooding of small- and medium-sized rivers [24] (see Figures 5 and 6). 


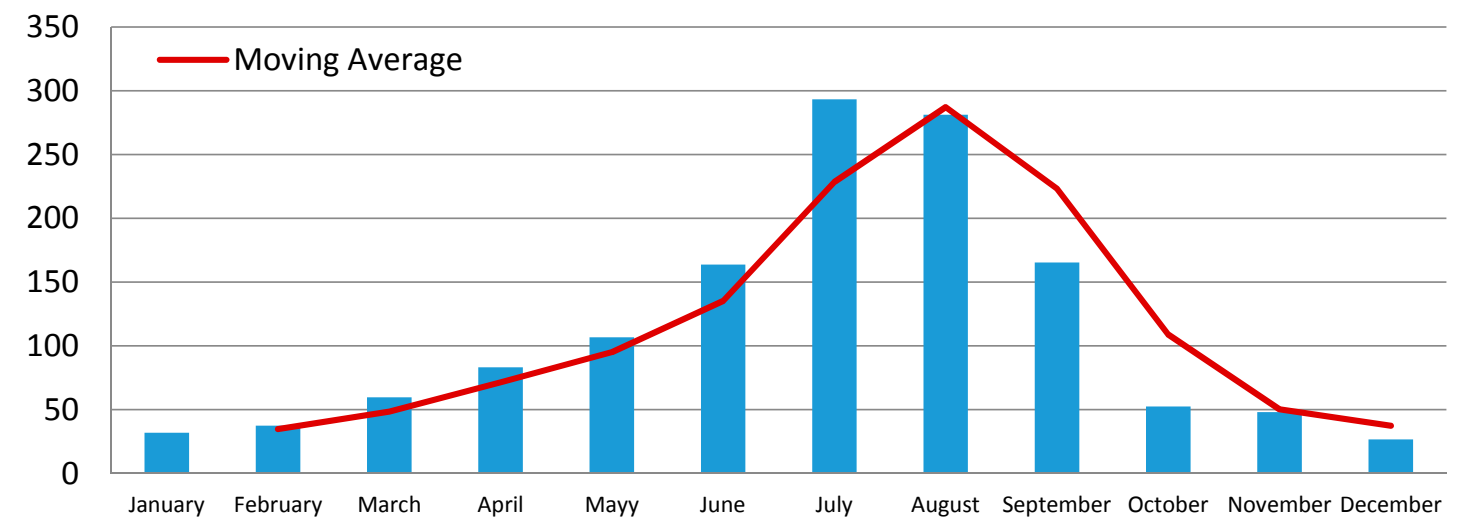

Figure 5. Monthly precipitation in Korea (mm), 1981-2010 (source: [25]).

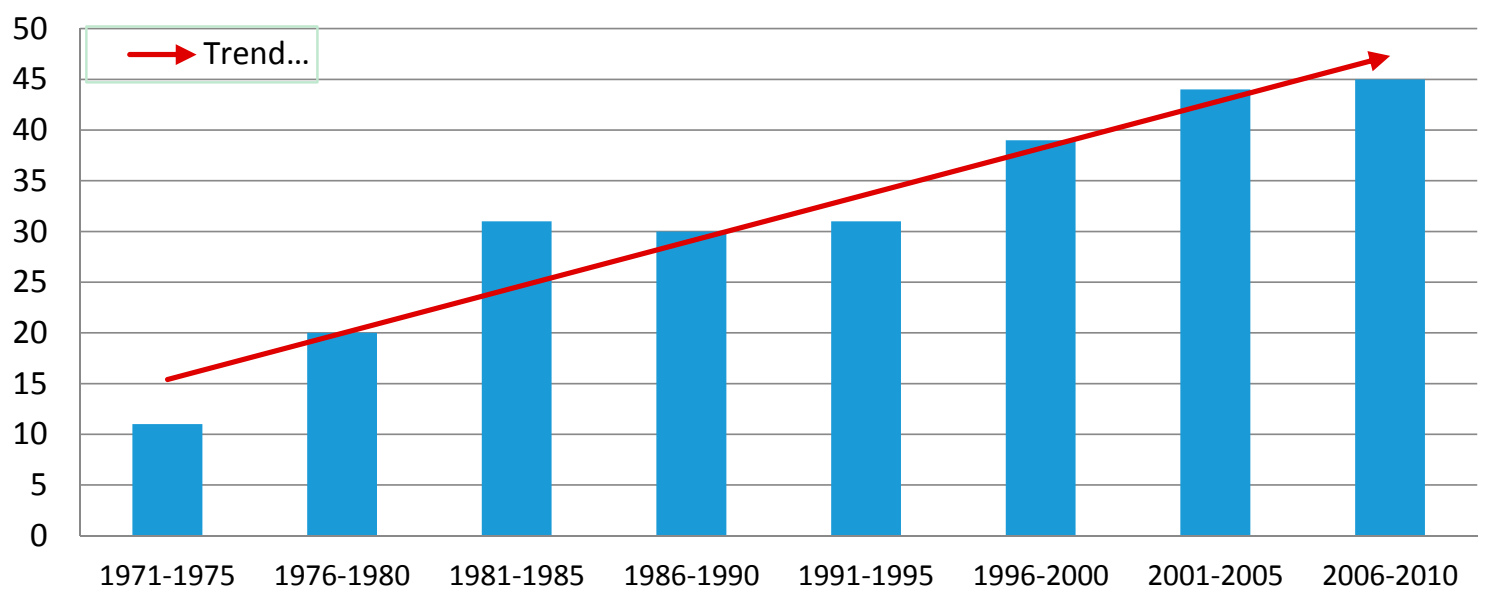

Figure 6. Hourly rainfall (top 1-5 rankings) in Korea (mm) (source: Kim, Sung and Lee [24]).

Thirdly, before 1980, flood damages in urban areas caused by severe rainstorms comprised inland and river flooding damages. In non-urban areas, flood damages after severe rainstorms were mostly caused by overflowing rivers due to ineffective levees, disrupted cross-sectional flow because of reduced river width, obsolete river facilities, and/or poor management. Table 2 summarizes this analysis.

Table 2. Summary of flood damage events (Source: [20]).

\begin{tabular}{|c|c|c|}
\hline \multirow{2}{*}{ Date } & \multicolumn{2}{|c|}{ Causes and Nature of Flooding } \\
\hline & Urban Area & Non-Urban Area \\
\hline 27-28 August 1962 & $\begin{array}{l}\text { River damage from prolonged } \\
\text { collapse of } 200 \mathrm{~m} \text { levee } \\
\text { and embankment } \\
\text { - } 2 / 3 \text { of city flooded }\end{array}$ & $\begin{array}{l}\text { - Prolonged collapse of levee } \\
\text { and embankment } \\
\text { Increase in water level and } \\
\text { stream flooding } \\
\text { - } \quad \text { Loss of farmland and lives }\end{array}$ \\
\hline 18-20 August 1972 & $\begin{array}{l}\text { - } \quad \begin{array}{l}\text { Flooding from river level exceeds } \\
\text { risk level (10.5 mm) }\end{array} \\
\text { - } \quad \begin{array}{l}\text { Flooding of } 7654 \text { houses due to lack } \\
\text { of drainage facilities }\end{array}\end{array}$ & $\begin{array}{l}\text { - } \quad \text { Flooding from river level exceeds } \\
\text { risk level }(10.5 \mathrm{~mm}) \\
\text { - } \quad \text { Farmland in low-lying areas } \\
\text { is submerged }\end{array}$ \\
\hline
\end{tabular}


Table 2. Cont.

\begin{tabular}{|c|c|c|}
\hline \multirow{2}{*}{ Date } & \multicolumn{2}{|c|}{ Causes and Nature of Flooding } \\
\hline & Urban Area & Non-Urban Area \\
\hline 20-22 July 1980 & $\begin{array}{l}\text { - Deterioration of river facilities and } \\
\text { installment of substandard facilities } \\
\text { - } \quad \text { Inundation of } 13,078 \text { houses from } \\
\text { levee collapse } \\
\text { - Lack of drainage facilities }\end{array}$ & $\begin{array}{l}\text { - River flooding due to rain overflow } \\
\text { of } 200-250 \text { years frequency } \\
\text { Lack of river maintenance, } \\
\text { including non-improvement of } \\
\text { small rivers, e.g., in } \\
\text { mountain valleys }\end{array}$ \\
\hline $\begin{array}{l}31 \text { August-3 September } \\
1984\end{array}$ & $\begin{array}{l}\text { Overflow due to low ground level } \\
\text { of riverside road } \\
\text { - Lack of flood control due to limited } \\
\text { extension of bridge and freeboard }\end{array}$ & $\begin{array}{l}\text { Overflow due to low ground level } \\
\text { of riverside road } \\
\text { - Lack of flood control due to limited } \\
\text { extension of bridge and freeboard }\end{array}$ \\
\hline 15-16 July 1987 & $\begin{array}{l}\text { - No high water revetment due to } \\
\text { low level of existing levee and } \\
\text { overflow from low levee height } \\
\text { Deterioration of flood damaged } \\
\text { areas near bridge }\end{array}$ & $\begin{array}{l}\text { Flooding of farmland and houses as } \\
\text { a result of lack of high water } \\
\text { revetment due to low level of } \\
\text { existing levee and } \\
\text { overflow / collapse of levee from } \\
\text { low levee height }\end{array}$ \\
\hline 25-27 July 1989 & $\begin{array}{l}\text { Predominantly urban damage due } \\
\text { to lack of sewer capacity and } \\
\text { malfunctioning of both drainage } \\
\text { system and flood pumping station }\end{array}$ & $\begin{array}{l}\text { Unregulated building of rural } \\
\text { housing in areas at risk from natural } \\
\text { disasters e.g., flood }\end{array}$ \\
\hline 9-12 September 1990 & $\begin{array}{l}\text { - } \quad \text { No serious flood damage, only } \\
\text { regional damage } \\
\text { Poor drainage system and lack of } \\
\text { sewer capacity }\end{array}$ & $\begin{array}{l}\text { - Area near riverside exposed to } \\
\text { flooding from overflow of nearby } \\
\text { river after heavy downpour } \\
\text { - Narrow river and levee }\end{array}$ \\
\hline $\begin{array}{l}30 \text { August-1 September } \\
2002\end{array}$ & $\begin{array}{l}\text { - } \quad \text { Problem with internal drainage } \\
\text { system from urban stream coverage } \\
\text { - Stream narrowing for } \\
\text { road expansion }\end{array}$ & $\begin{array}{ll}\text { - } & \text { Lack of water cross section in stream } \\
\text { - } & \text { Insufficient size of stream structures } \\
\text { - } & \text { Limited stream maintenance }\end{array}$ \\
\hline 12-13 September 2003 & $\begin{array}{l}\text { - Construction of housing in low } \\
\text { lying areas without additional } \\
\text { construction of drainage system } \\
\text { Interruption in drainage discharge } \\
\text { due to concentrated railroad and } \\
\text { road bridges around stream } \\
\text { crossing the city }\end{array}$ & $\begin{array}{l}\text { Damage due to geological factors } \\
\text { (steep area) } \\
\text { Damage to essential services, } \\
\text { including a water pipe built near } \\
\text { the stream becoming scoured and } \\
\text { lost during overflow }\end{array}$ \\
\hline 9-29 July2006 & $\begin{array}{l}\text { - } \quad \begin{array}{l}\text { No flood damage to city as a result } \\
\text { of city planning avoiding } \\
\text { low-lying ground }\end{array} \\
\text { - } \quad \text { However, damages caused in } \\
\text { nearby cities and developing areas } \\
\text { - } \quad \text { Traffic chaos from road flooding } \\
\text { - Drainage problem caused by } \\
\text { heavy rainfall }\end{array}$ & $\begin{array}{l}\text { - Flood damage from influx of trees } \\
\text { and sand from mountains into small } \\
\text { stream areas } \\
\text { Inadequate and deteriorating } \\
\text { drainage system }\end{array}$ \\
\hline
\end{tabular}




\subsection{Intervention Effects of Structural and Non-Structural Measures on Flood Damages}

In Korea, full-scale policy interventions in the form of structural and non-structural flood mitigation measures occurred in 1965 and 1991, respectively. Therefore, 1965 and 1991 are set as the points of policy interventions to tackle damages in flood-affected areas and damages to human life, respectively. Figures 7 and 8 show the graphs depicting flood-affected areas and damages to human life, respectively. Both sets of data indicate a changing trend across time. Accordingly, the first difference is attempted for stabilization (see Figures 9 and 10). Next, a unit roots test is conducted to assess the quantitative stability using the Dickey-Fuller test. The statistical hypothesis is that first-difference data do not have a unit root $(p \neq 1)$. The computed $\mathrm{p}$-value is 0.10 , thereby rejecting the null hypothesis that $p=1$. Therefore, stationarities are secured through the first difference.

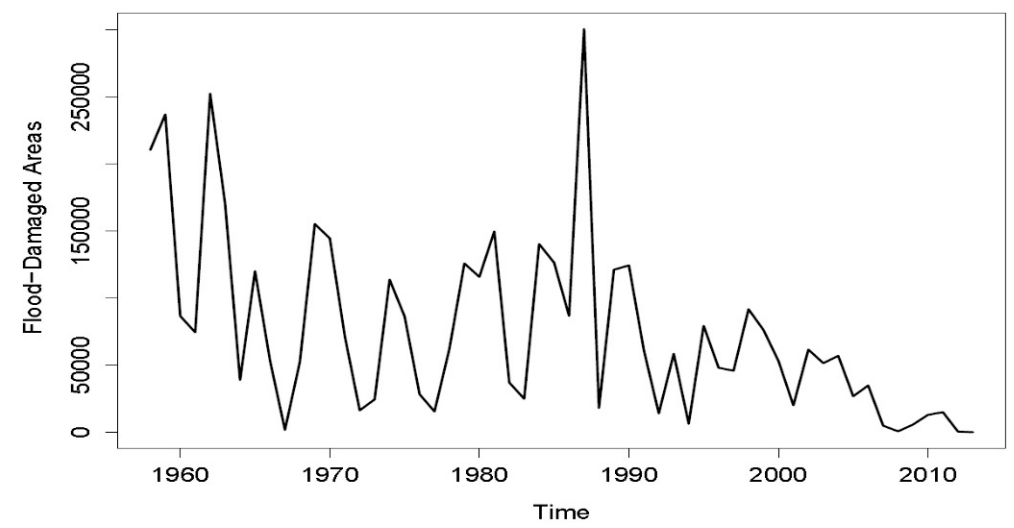

Figure 7. Original data on flood-affected areas (source: [26]).

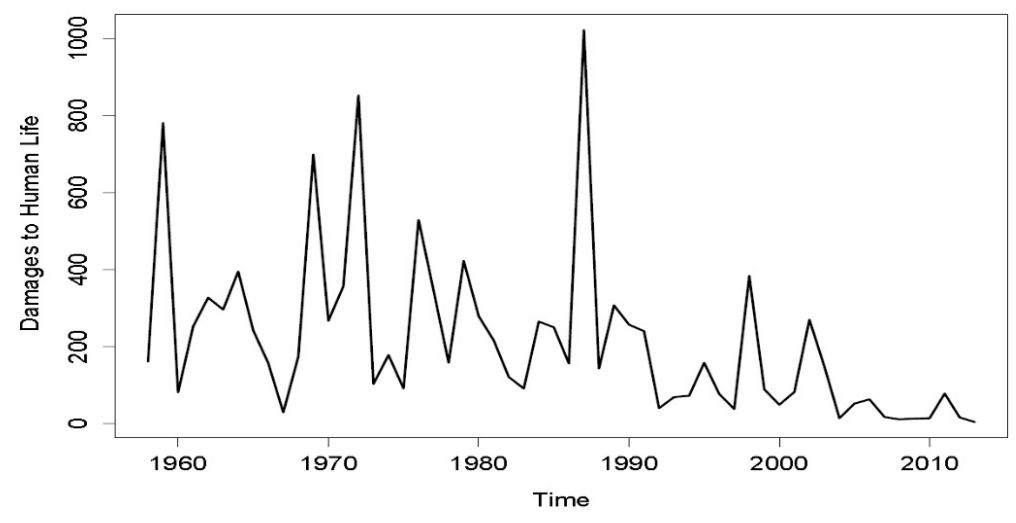

Figure 8. Original data on damages to human life (source: [26]).

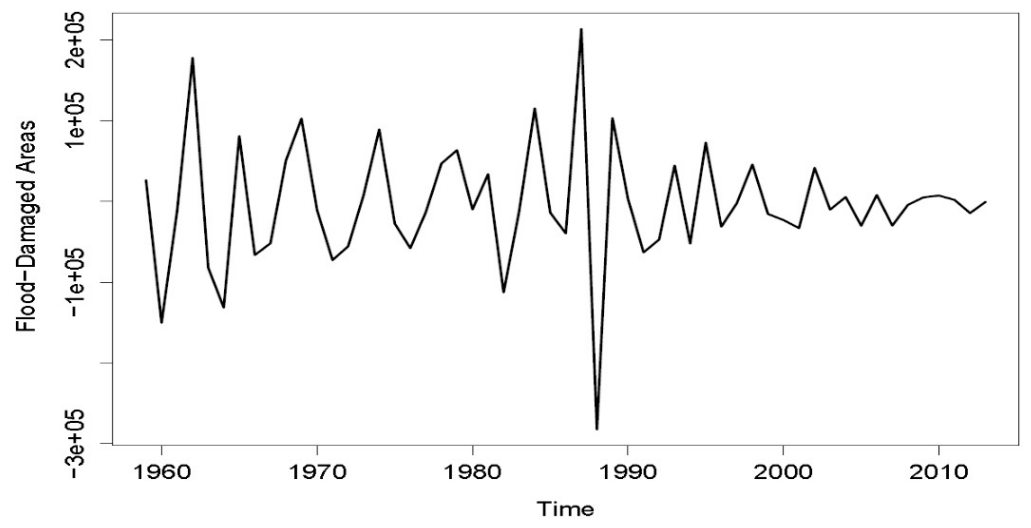

Figure 9. First difference of flood-affected areas (source: [26]). 


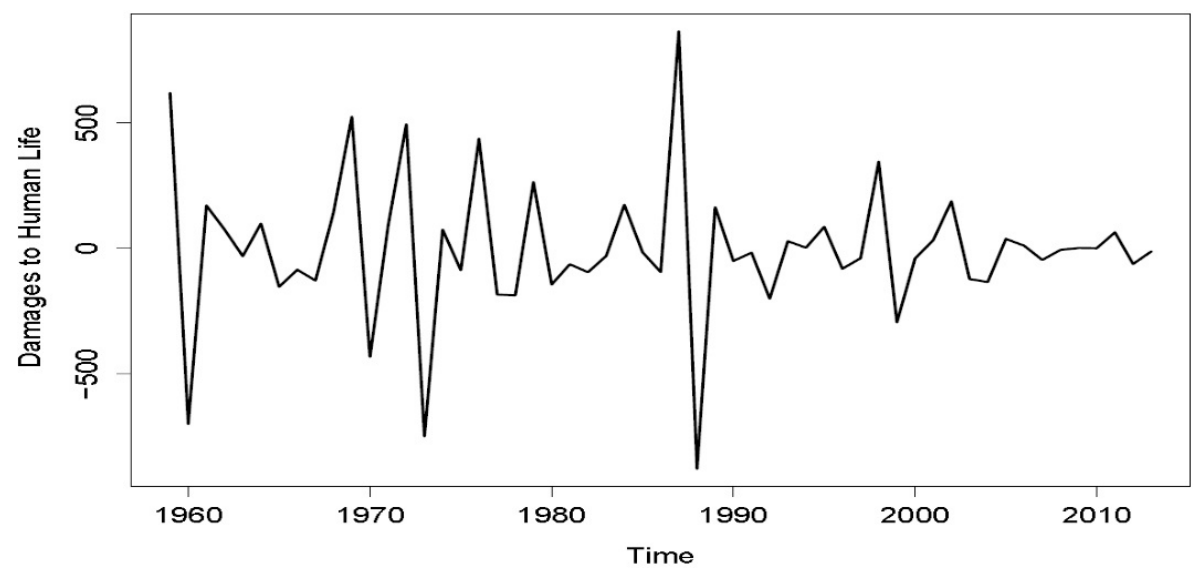

Figure 10. First difference of damages to human life (source: [26]).

Then, the model is identified using the Auto Correlation Function (ACF) and Partial Auto Correlation Function (PACF) (Figures 11-14). After repeating the identification and estimation of the model, it is determined that ARIMA $(0,1,1)$ is a suitable final model for both analyses.

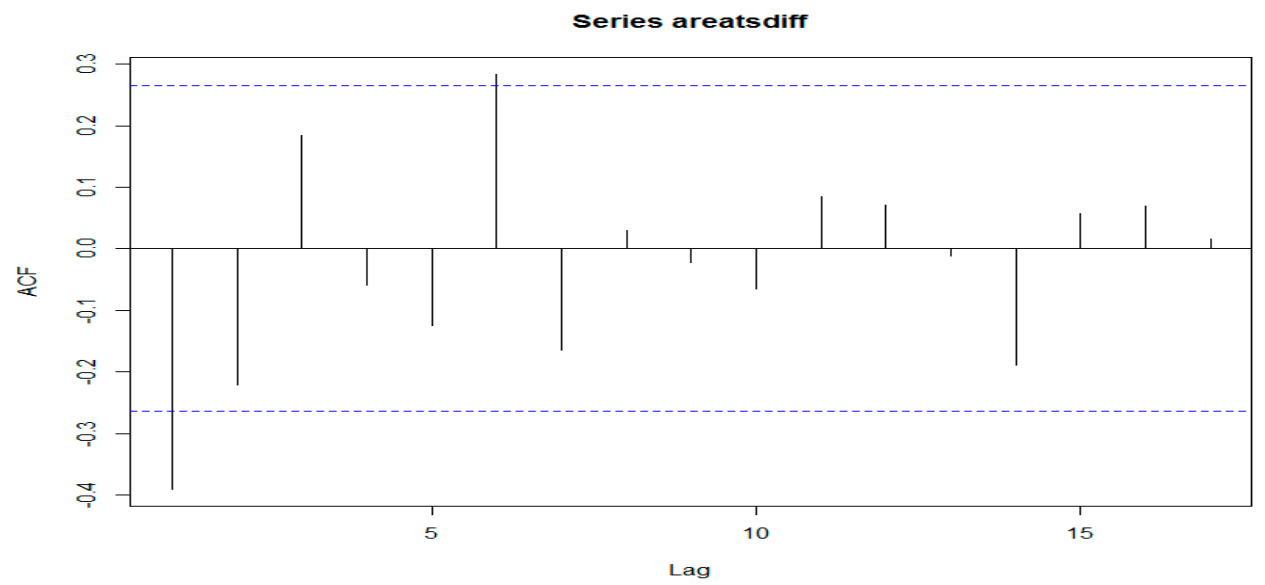

Figure 11. Auto Correlation Function (ACF) of flood-affected areas.

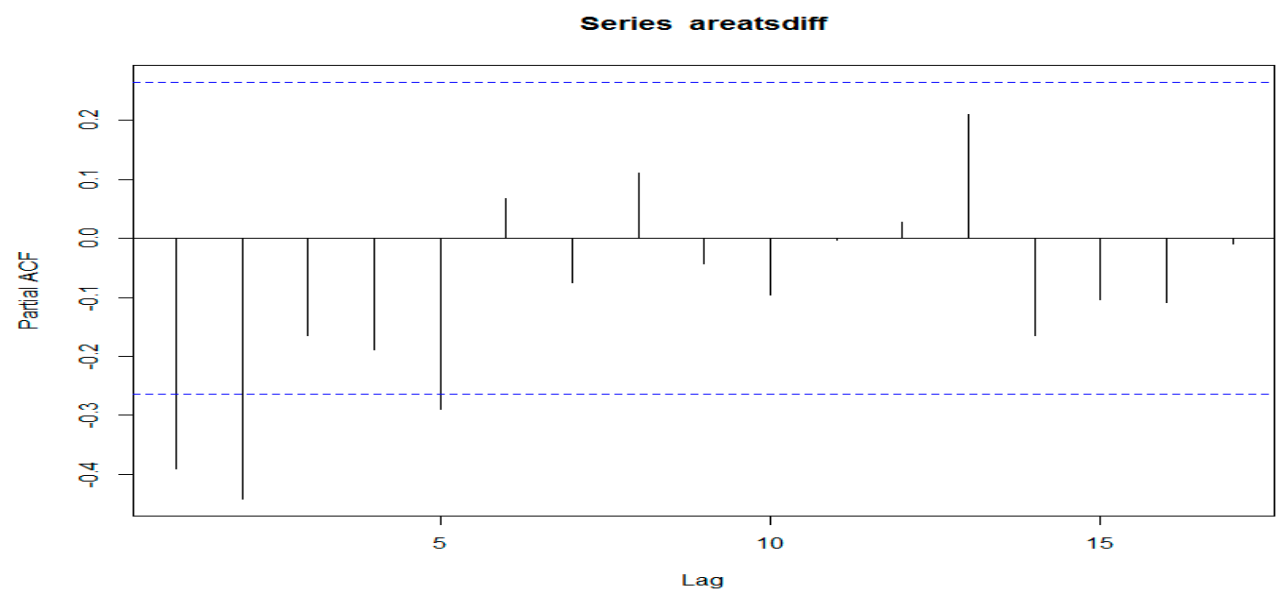

Figure 12. Partial Auto Correlation Function (PACF) of flood-affected areas. 


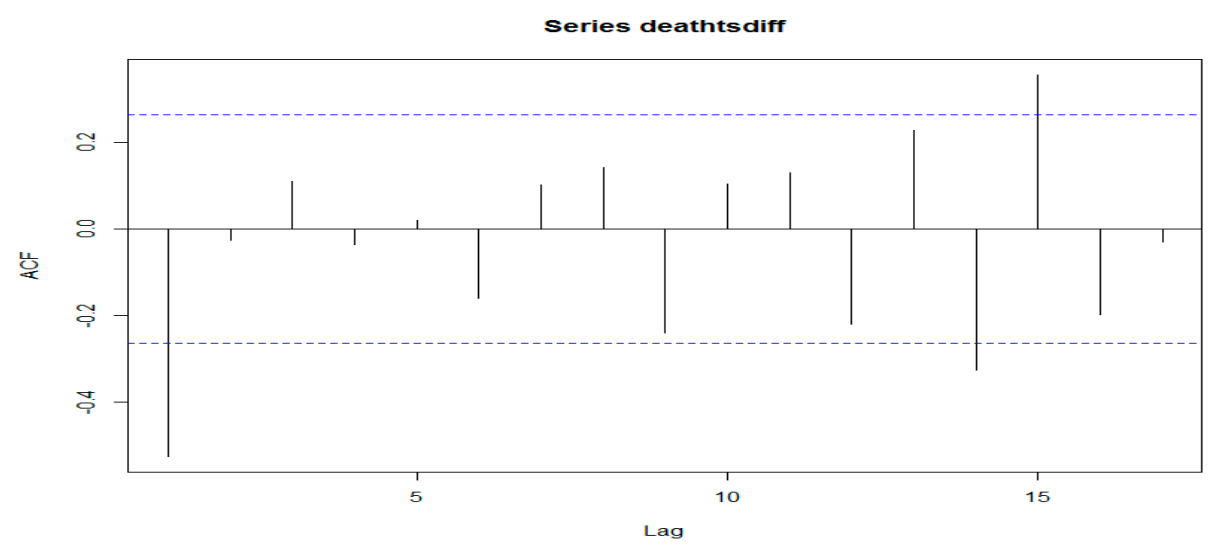

Figure 13. ACF of damages to human life.

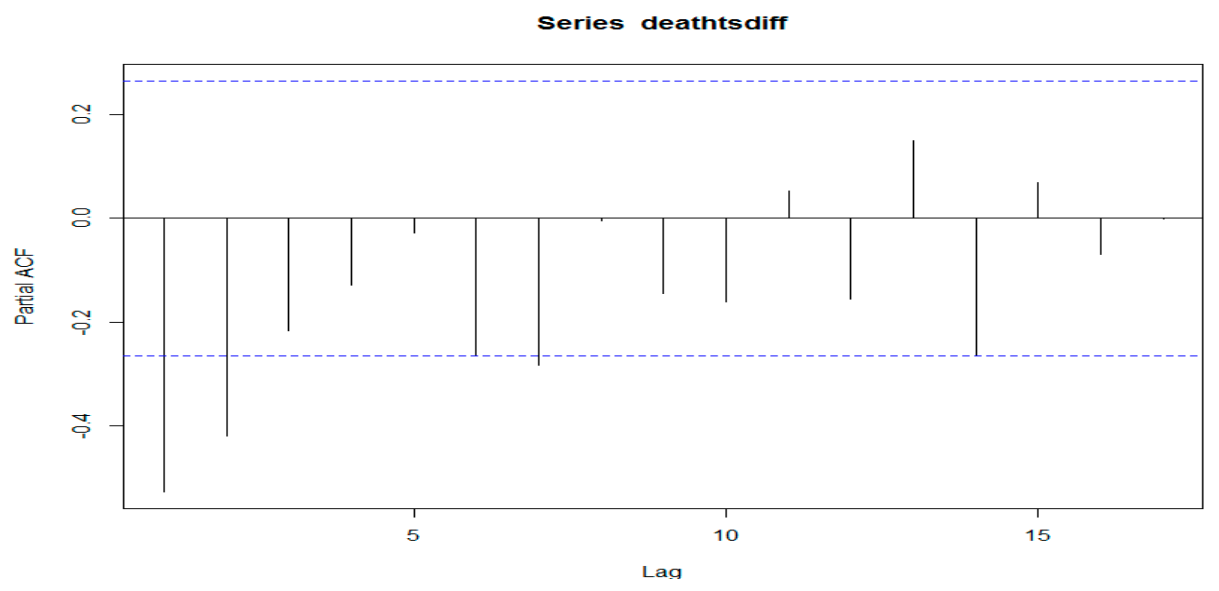

Figure 14. PACF of damages to human life.

The term $Y_{t}$, indicates the original time series data of the flood-affected areas, and $Y^{\prime}{ }_{t}$ indicates the original time series data of damages to human life. The estimated model is significant at $p<0.05$ (see Equations (5) and (6)). The values within the parentheses indicate the standard error terms. Moreover, the quality level of white noise is satisfied in the ACF, PACF, and Ljung-box tests of the estimated model.

$$
\begin{gathered}
(1-B) Y_{t}=a_{t}-\theta_{1} a_{t-1} \cdots \cdot \theta=-0.7686(0.0949) \\
(1-B) Y_{t}^{\prime}=a_{t}-\theta_{1} a_{t-1} \cdots \cdot \theta^{\prime}=-0.8737(0.0556)
\end{gathered}
$$

Next, we analyze the intervention effects. The form of the intervening variables is based on the section in which the extent of deviation from the mean changes rapidly when the characteristics of flood damages are applied. Therefore, the intervention effects of the structural measures in 1965 can be modeled in the following ways: (1) the point where the structural measures start to influence flood damage mitigation after 1965 and (2) the point after which the flood damage mitigation effects gradually increase to a certain level because of policy intervention. The intervention effects of the non-structural measures in 1991 are different: (1) the non-structural measures start to influence flood damages mitigation immediately in 1991, and (2) the flood damages mitigation effects occur continuously at a certain level after the policy intervention. Therefore, the effects of the intervening variables are defined as follows in Equations (7) and (8). $m t$ and $m t^{\prime}$ refer to the intervention effect on flood-affected areas and damages to human life, respectively.

$$
m t=\frac{\omega \cdot B}{1-B} S_{t}\left(1965_{\text {year }}\right)
$$




$$
m t^{\prime}=\omega \cdot S_{t}\left(1991_{\text {year }}\right)
$$

Intervening variables, as shown in Equations (7) and (8), are used to determine the influences by accounting for the effects of the flood prevention policies. The final intervention models that applied the intervention effect $m t$ are Equations (9) and (10) as independent variables in the ARIMA $(0,1,1)$ model before the interventions.

$$
\begin{gathered}
Y_{t}=\frac{\omega \cdot B}{1-B} S_{t}^{(T=1965)}+\frac{a_{t}-\theta_{1} a_{t-1}}{1-B} \\
Y_{t}^{\prime}=\omega \cdot S_{t}^{(T=1991)}+\frac{a_{t}-\theta_{1} a_{t-1}}{1-B}
\end{gathered}
$$

As shown in Table 3, the distribution of white noise is estimated with the maximum likelihood estimation, which assumes a normal distribution. In both models, the intercept $\theta_{0}$ is eliminated because it is not significant at $p<0.05$, and the suitability of the models is verified by the residual test (ACF diagram, PACF diagram, and portmanteau test) on the estimated model (see Figures 15 and 16).

Table 3. Estimated results of the intervention time series model.

\begin{tabular}{ccccc}
\hline Classification & \multicolumn{2}{c}{ Flood-Affected Areas } & \multicolumn{2}{c}{ Damages to Human Life } \\
\hline Parameter & $\theta$ & $\omega$ & $\theta$ & $\omega^{\prime}$ \\
Estimate & -0.853 & -70.594 & -0.988 & -216.259 \\
Standard & 0.075 & 33.486 & 0.049 & 50.956 \\
error & -11.251 & -2.108 & -20.156 & -4.244 \\
$z$-score & $0.001^{* * *}$ & $0.05^{*}$ & $0.001^{* * *}$ & $0.001^{* * *}$ \\
$p$-value & $\hat{\sigma}=3.582 e+09, A I C=1371.31$ & $\hat{\sigma}=35194, A I C=7399.88$ \\
& ${ }^{*}=p<0.05^{* *}=p<0.011^{* * *}=p<0.001$, two-tailed tests.
\end{tabular}
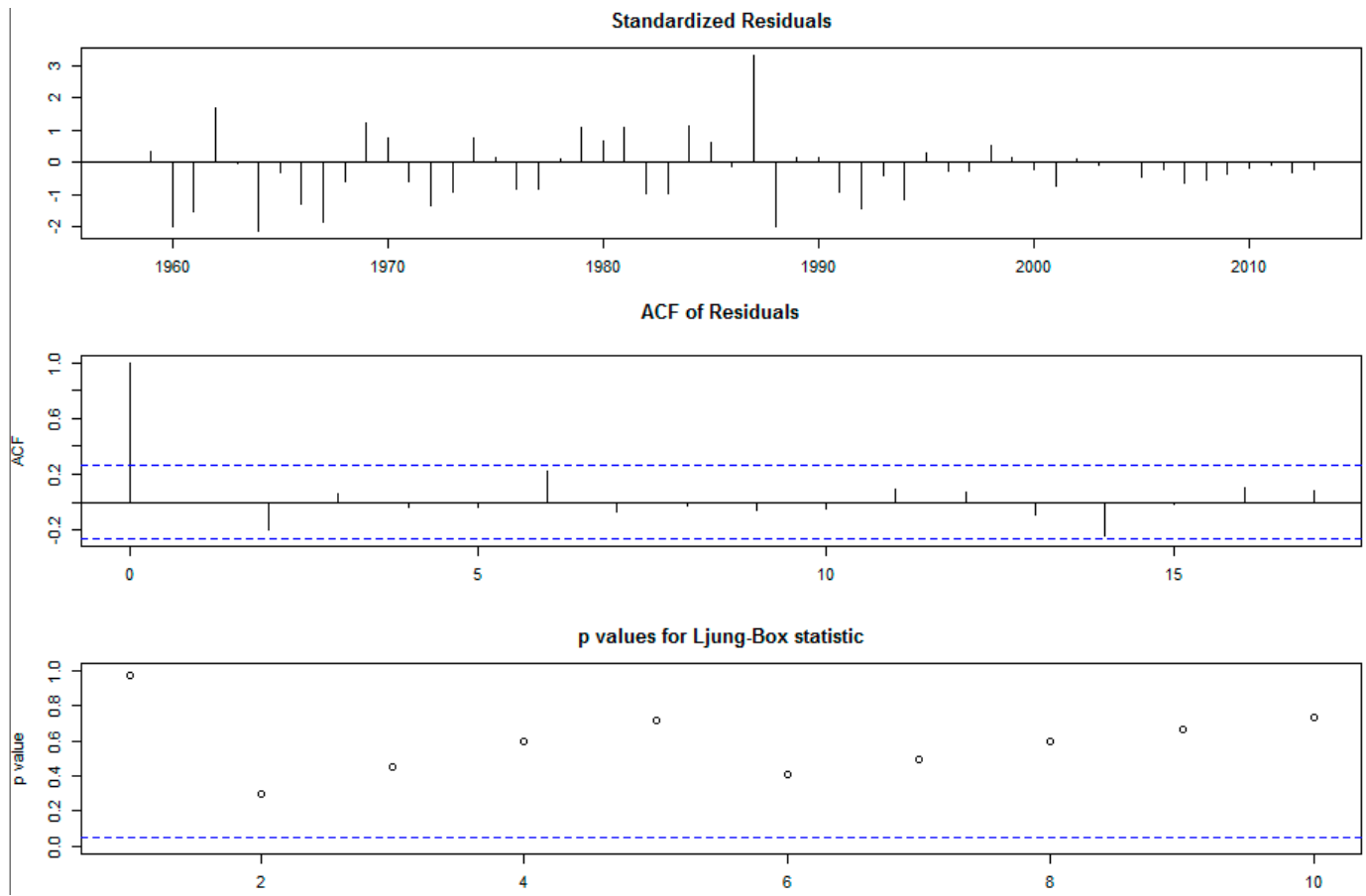

Figure 15. Suitability assessment of flood-affected areas. Note: Ignore the significant spikes other than the first two time differences and those that appear regularly. 


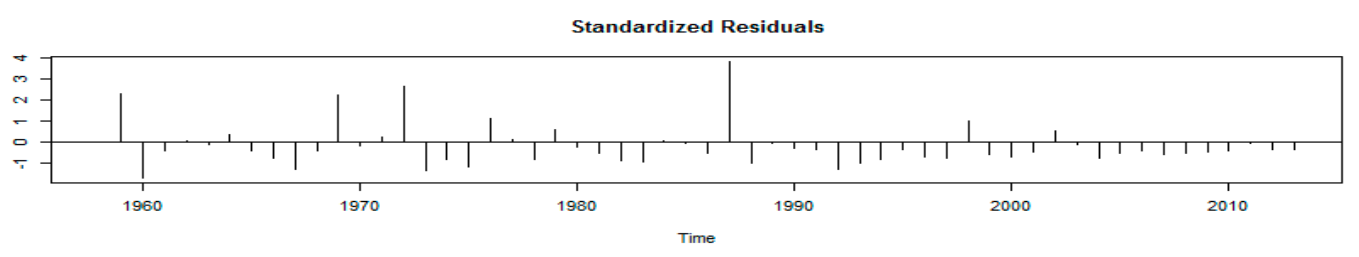

ACF of Residuals

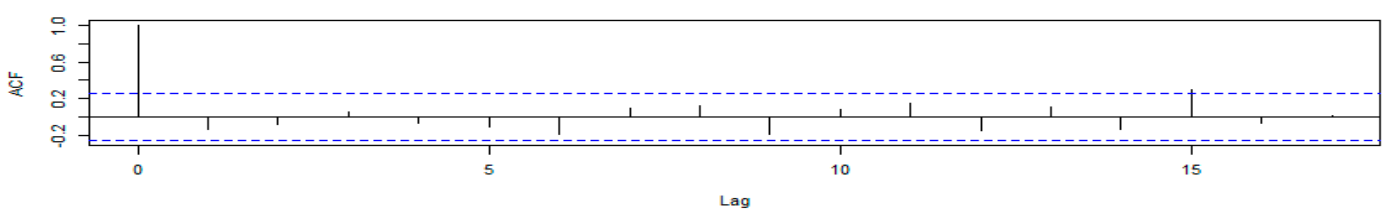

p values for Ljung-Box statistic

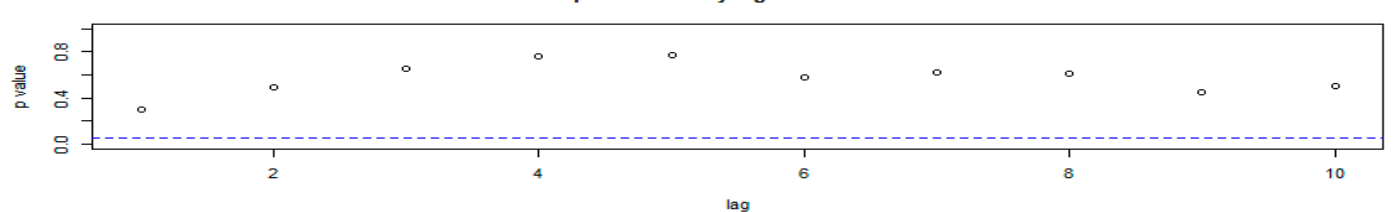

Figure 16. Suitability assessment of damages to human life. Note: Ignore the significant spikes other than the first two time differences and those that appear regularly.

According to the final model, $\omega$ and $\omega^{\prime}$ are negative because of the effects of the structural and non-structural measures in 1965 and 1991, respectively, thereby rejecting the statistical null hypothesis $\left(\omega_{i}=0\right)$ of no intervention effects. In other words, the policy interventions concerning structural measures in 1965 influenced the size of the flood-affected areas, which decreased by 70,594 ha on average (amounting to a reduction of 48.5 percent) over the entire study period. In addition, damages to human life decreased by 216 persons on average over the entire study period (a reduction of 71.3 percent), on account of policy interventions enacted in 1991 for the non-structural measures. Very importantly, in the estimated model, the data on flood-affected areas and casualties are influenced by the past moving average. This implies that flood-affected areas and damages to human life are more significantly influenced by unaccounted for external variables than by values of the past, and that, therefore, long-term forecasting in those respects is impossible.

$$
\begin{aligned}
& Y_{t}=\frac{-70.594 B}{1-B} S_{t}^{(T=1965)}+\frac{(1+0.85 B)}{1-B} a_{t} \\
& Y_{t}^{\prime}=-216.25 \cdot S_{t}^{(T=1991)}+\frac{(1+0.98 B)}{1-B} a_{t}
\end{aligned}
$$

\section{Discussion}

As stated previously, some of the important policy interventions that influenced mitigation of flood damages in Korea refer to structural measures, such as river management and flood control projects, which started in 1965, and non-structural measures, such as prior evacuation plans, which started in 1991. Figures 17 and 18 illustrate these policy interventions. 


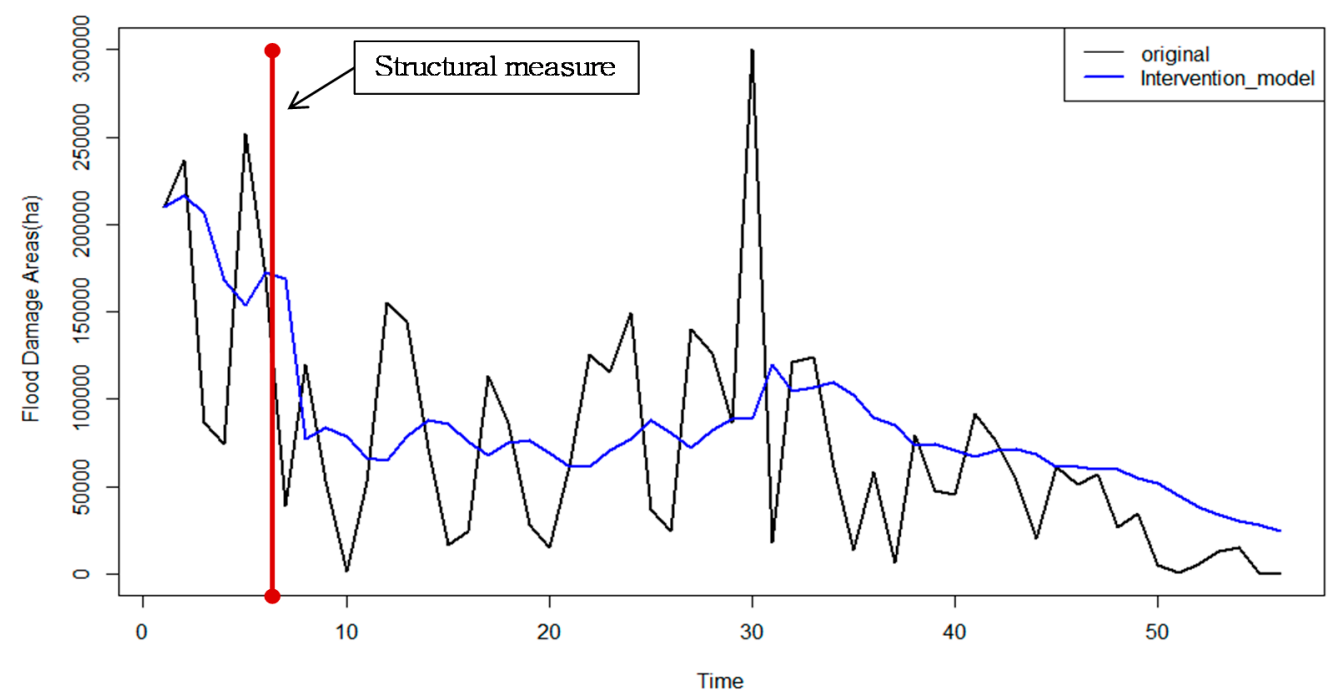

Figure 17. Raw data and the estimated intervention model (structural measures).

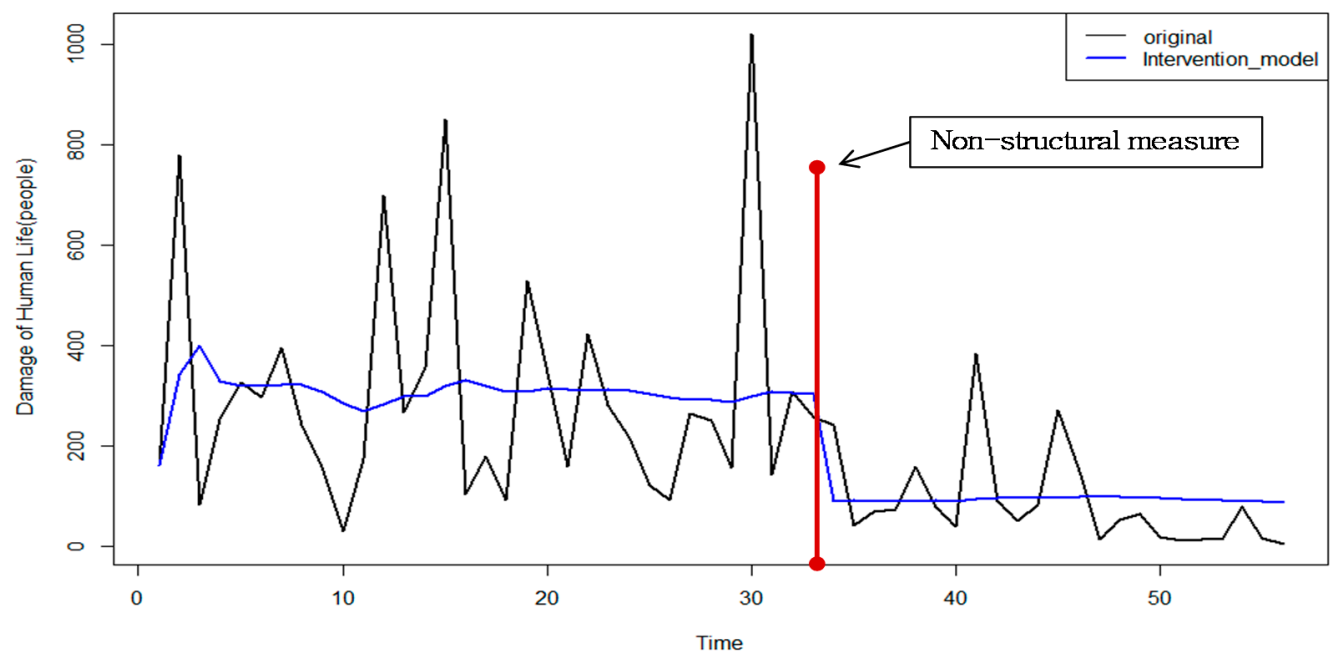

Figure 18. Raw data and the estimated intervention model (non-structural measures).

First, the intervention effects of the structural measures gradually influenced flood damages after policy implementation. The size of the intervention effects can be mainly attributed to the continuous and annual structural river management and flood control projects since 1965. However, the reduction in the size of the flooded areas does not necessarily mean lower flood damages, because the monetary amount of damages to public facilities and private property continues to increase (Figure 19).

Moreover, when the monetary amount of the flood damages is divided by the number of unit areas, flood damages are shown to have increased compared to those before 1960. This is because the rapid economic growth in Korea has increased the urbanization rate by 90 percent over the past 50 years, resulting in a rise in the area of impermeable surfaces and increased run-off in urban areas. Rivers were paved over to be used as roads or for residential development, and the narrowing of the river width distorts the water flow. As a result, flood damages, which had mostly occurred in non-urban areas, such as agricultural lands, now occur frequently in urban areas [27]. Although flood damages continue to occur in non-urban areas, mostly caused by obsolete defense facilities and poor river management, the resulting damages are expected to be relatively greater in the cities because of their higher densities of goods and population. 


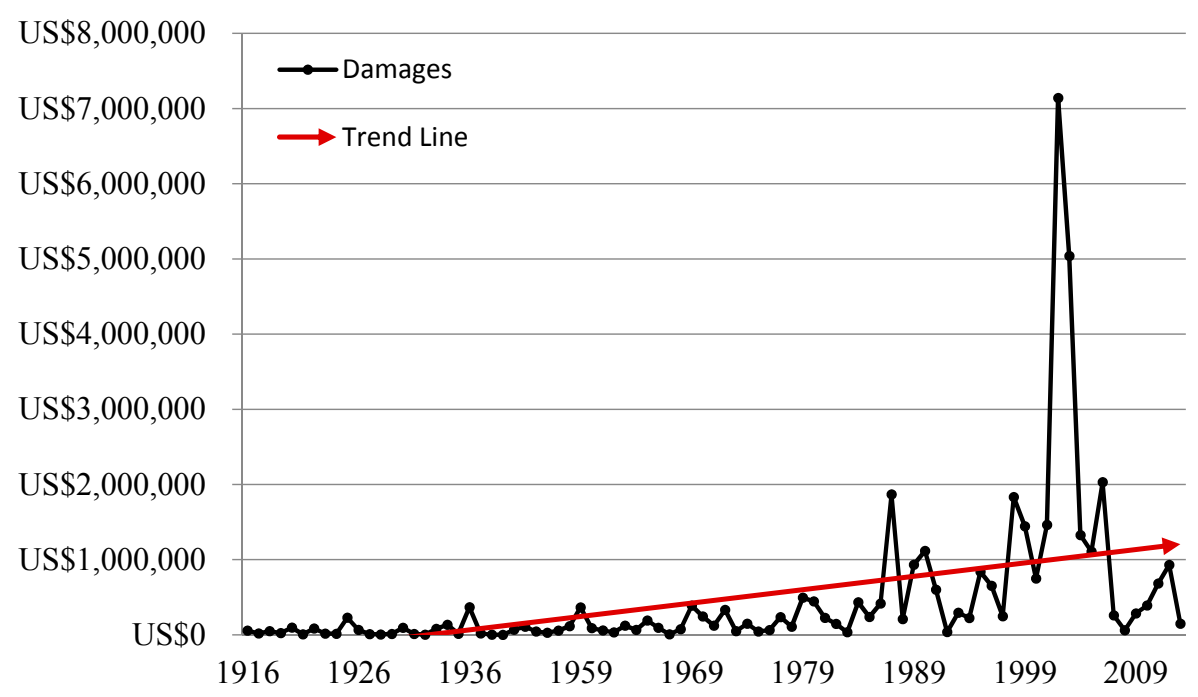

Figure 19. Trend in flood damages from 1916 to 2013, except 1945 to 1957 (conversion basis price in USD, 2013) (source: [20]).

The analysis of the effects of interventions for non-structural measures indicates that damages to human life decreased over the study period by 216 people on average. Further, the effects of the interventions occurred immediately upon implementation, substantially owing to prior evacuation measures based on improved weather information and communications. This result verifies the benefits of flood forecasting and warning systems as argued by the 2014 UNISDR Report [22]. Similar conditions exist in Japan and Bangladesh. Japan introduced computerized weather forecasts in 1959, and damages to human life rapidly decreased from 1960 to the present. In addition, this change is closely correlated with the television penetration rate [28]. An analysis of damages to human life caused by major cyclones in coastal Bangladesh showed that the number of fatalities decreased from 138,882 in 1991 to 134 in 1997, after the forecasting system was implemented [29].

Current damages to human life are mainly caused by flash floods in the mountainous areas (about 70 percent of Korean territory is mountainous with scattered basins), indiscreet development, and inappropriate land use in areas vulnerable to flood damages. In 2007, damages to human life by floods were attributed to rapidly rising streams in the valleys, and river overflow; 46 of every 50 people who suffered damage resided in the mountainous areas [30]. Other damages were caused by rampant cutting of forests and the construction of sprawling amusement parks (amounting to 50 deaths in 1998) [30]. Additional details on this topic can be found in studies that analyzed the causes of flood damages in Korea [31,32].

Thus, in summary, while the flood-affected areas decreased in size through policy intervention effects, namely, the amendment to the River Act, the flood damages per se (flood prevention effects) did not decrease. Thus, Korea needs a specific policy/intervention that addresses flood damages. Regarding non-structural measures, this study finds that the flood forecasting and warning systems in Korea are insufficient at this time, and that it is important to accurately predict and notify the public about imminent floods to reduce the associated damages. Moreover, the administrative agencies must be criticized for not taking the necessary steps to prevent sprawling development in mountainous areas or other areas vulnerable to floods. Table 4 lists the policy recommendations for structural and non-structural measures based on this study's results. 
Table 4. Policy recommendations for structural and non-structural measures.

\begin{tabular}{|c|c|}
\hline Category & Content \\
\hline $\begin{array}{l}\text { Structural } \\
\text { measures }\end{array}$ & $\begin{array}{l}\text { The existing facilities should be reinforced. Many dams and embankments on big and small } \\
\text { rivers in Korea were constructed many decades ago; hence, the repair work, such as functional } \\
\text { reinforcement, must be performed in light of the significant changes to rainfall patterns since } \\
\text { then. Moreover, repair and upgrading can prevent obsolescence of the embankment facilities } \\
\text { and reduce future risk of destruction. } \\
\text { The natural environment of the damaged rivers should be recovered. Even in the absence of } \\
\text { their ecological or landscape functions, rivers can prevent floods by reducing the flow velocity. } \\
\text { Mitigation measures for urban areas must be established. While damages caused by poor } \\
\text { drainage of inner basins are severe in urban areas, the measures to solve this problem are } \\
\text { presently insufficient. Drainage facilities should be continually expanded and managed, and the } \\
\text { coordination between rainwater and flood control measures should be improved. }\end{array}$ \\
\hline $\begin{array}{l}\text { Non-structural } \\
\text { measures }\end{array}$ & $\begin{array}{l}\text { The ability to forecast floods to cope with local flash flooding caused by extreme weather must } \\
\text { be enhanced. A rainfall-flood forecasting system should be created and technologies related to } \\
\text { flood forecasting should be implemented to facilitate immediate response to all meteorological } \\
\text { and hydrological situations that could influence the rapidly changing river flows that occur } \\
\text { in floods. } \\
\text { The government must adequately and promptly warn residents and order evacuations in } \\
\text { emergencies. To this end, the government must draw up a plan for flood-related laws and } \\
\text { integrate the administrative system. } \\
\text { Flood damages must be prevented by rational land-use planning and management. It is } \\
\text { necessary to establish the pre-meditated approaches to land use that limit the construction of } \\
\text { buildings in vulnerable areas. }\end{array}$ \\
\hline
\end{tabular}

\section{Conclusions}

The objectives of this study were to empirically analyze the characteristics of flood damages in Korea and the effects of Korea's structural and non-structural flood prevention mitigation measures on the extent of flood damages from 1958 to 2013 (a period of 55 years).

First, we theoretically discussed the structural and non-structural mitigation measures for flood damage prevention, upon which we based our general hypothesis and variable selection. Then, we performed a qualitative analysis using data on measures of human, social, economic, and precipitation characteristics as well as events causing flood damages, to examine changes and trends over space and time. Finally, we analyzed the effects of flood prevention measures in an intervention time series model to arrive at conclusions and develop policy suggestions.

The major results of this study are as follows:

- The intervention effects of structural and non-structural measures analyzed using time series data covering the past 55 years were significant. Structural intervention effects emerged slowly in flood-affected areas, whereas the non-structural effects on damages to human life were immediate

- The analysis of the characteristics of flood damages found that structural measures did not reduce flood damages, because no measures accounted for flood risk factors, or changes to the socioeconomic factors and population growth, which accompany rapid urbanization. On the other hand, non-structural measures, including prior (prevention) planning based on information from computerized weather information systems, were successful in reducing flood damages

- Based on the overall results of this study, we provided policy suggestions for flood mitigation measures in Korea. For structural measures, we suggested upgraded reinforcements and management of the existing facilities, ecosystem recovery for damaged rivers, and new/modernized flood mitigation measures for urban areas. For non-structural measures, we suggested enhanced flood forecasting, revamping the legal regulations on flood control, and new and rational land-use plans 
This study is important because its results demonstrate the effects of existing policy measures on flood damages control in Korea and because it employs reliable analytical methods to suggest potential future flood damage prevention mitigation measures and sound policy decisions.

Acknowledgements: This research was supported by the Basic Science Research Program through the National Research Foundation of Korea (NRF) funded by the Ministry of Science, ICT and Future Planning (NRF-2011-0028914). Furthermore, this paper was published as a conference article presented at the International Congress of Asian Planning Schools Association in August 2015.

Author Contributions: Cheol-Hee Son conceived the idea for the analysis and drafted the manuscript. Join-In Back contributed to data collection on socioeconomic factors and flood damages. Yong-Un Ban and Sung-Ryong Ha were the supervisors of the original thesis from which this paper is drawn. All authors have read, provided feedback on, and approved the final manuscript.

Conflicts of Interest: The authors declare no conflict of interest.

\section{References}

1. Kwon, Y.; Park, J.; Kim, T. Estimation of design rainfalls considering an increasing trend in rainfall data. J. Korean Soc. Civ. Eng. 2009, 29, 131-139.

2. Park, T.; Kim, G.; Yoon, Y.; Lee, S. Analysis of Flood Damage Characteristics and Development of Flood Damage Index; Korea Research Institute for Human Settlements: Daejeon, Korea, 2005.

3. Thampapillai, D.J.; Musgrave, W.F. Flood damage mitigation: A review of structural and nonstructural measures and alternative decision frameworks. Water Resour. Res. 1985, 21, 411-424. [CrossRef]

4. Alexander, D. Natural Disasters; Springer Science \& Business Media: New York, NY, USA, 1993.

5. Few, R. Flooding, vulnerability and coping strategies: Local responses to a global threat. Prog. Dev. Studies 2003, 3, 43-58. [CrossRef]

6. Lung-Sheng, H.; Ming-Hsi, H.; Ming-Hsu, L. An assessment of structural measures for flood-prone lowlands with high population density along the keelung river in Taiwan. Nat. Hazards 2006, 37, 133-152.

7. Ahn, J. Flood Mitigation Analysis for Abnormal Flood at Namhangang River Basin. Master's Thesis, Ajou University, Suwon, Korea, 2015.

8. Poussin, J.K.; Botzen, W.W.; Aerts, J.C. Effectiveness of flood damage mitigation measures: Empirical evidence from french flood disasters. Glob. Environ. Change 2015, 31, 74-84. [CrossRef]

9. Schröter, K.; Ostrowski, M.; Velasco, C.; Torres, D.S.; Nachtnebel, H.P.; Kahl, B.; Beyene, M.; Rubin, C.; Gocht, M. First Crue Era-Net Common Call Effectiveness and Efficiency of Non-Structural Flood Risk Management Measures. Available online: https://www.researchgate.net/profile/Manfred_Ostrowski/ publication/255947664_Effectiveness_and_Efficiency_of_Early_Warning_Systems_for_Flash-Floods_\%28 EWASE\%29/links/0deec520e2963ab76f000000.pdf (accessed on 21 December 2015).

10. Faisal, I.; Kabir, M.; Nishat, A. Non-structural flood mitigation measures for dhaka city. Urban Water 1999, 1, 145-153. [CrossRef]

11. Manoloche, D. Alternative approach to flood risk modelling. In Proceedings of the 5th Victorian Flood Management Conference, Warrnambool, Australia, 9-12 October 2007.

12. Somek, D. Flood risk reduction-an assessment of costs and benefits. In Proceedings of the 11th IWA Young Water Professionals Conference, Sydney, Australia, 5-7 July 2010.

13. Jonkman, S.; Bočkarjova, M.; Kok, M.; Bernardini, P. Integrated hydrodynamic and economic modelling of flood damage in the Netherlands. Ecol. Econ. 2008, 66, 77-90. [CrossRef]

14. Dawson, R.; Hall, J. Adaptive importance sampling for risk analysis of complex infrastructure systems. In Proceedings: The Royal Society of London A: Mathematical, Physical and Engineering Sciences; The Royal Society: London, UK, 2006; pp. 3343-3362.

15. Van Stokkom, H.T.; Smits, A.J.; Leuven, R.S. Flood defense in the Netherlands: A new era, a new approach. Water Int. 2005, 30, 76-87. [CrossRef]

16. Dos Santos, P.P.; Tavares, A.O. Basin flood risk management: A territorial data-driven approach to support decision-making. Water 2015, 7, 480-502. [CrossRef]

17. Gutiérrez, F.; Parise, M.; De Waele, J.; Jourde, H. A review on natural and human-induced geohazards and impacts in karst. Earth Sci. Rev. 2014, 138, 61-88. [CrossRef] 
18. Jung, H.S.; Choi, Y.; Oh, J.H.; Lim, G.H. Recent trends in temperature and precipitation over South Korea. Int. J. Climatol. 2002, 22, 1327-1337. [CrossRef]

19. Statistics Korea. 2010 Population and Housing Census; Statistics Korea: Daejeon, Korea, 2011.

20. National Emergency Management Agency. Annals of Disasters 2013; National Emergency Management Agency: Seoul, Korea, 2014.

21. Haok, J.; Jaeik, H.; Sangu, P. Development of hydrological shared vision model for conflict mediation of dam construction. J. Korea Water Resour. Assoc. 2012, 45, 1009-1022.

22. New Zealand Superannuation Fund. Annual Report 2014; New Zealand Superannuation Fund: Auckland, New Zealand, 2014.

23. Box, G.E.; Jenkins, G.M. Time Series Analysis: Forecasting and Control, 2nd ed.; Holden-Day: San Francisco, CA, USA, 1976.

24. Kim, Y.; Sung, J.; Lee, J. Analysis of the recent flood characteristics in korea. Mag. Korea Water Resour. Assoc. 2014, 47, 35-40.

25. Korea Meteorological Administration. Weather Yearbook 2014; Korea Meteorological Administration: Seoul, Korea, 2015.

26. Water management information system, WAMIS. Available online: http:/ /www.wamis.go.kr (accessed on 20 December 2015). (in Korean).

27. Kang, S.; Lee, Y. Flood measures during the rainy season for an angel of the selection. Issues Diagn. 2011, 6, $1-25$.

28. Lee, J.; Jeon, Y.; Ahn, J.; Kim, T. A method for selecting a structural optimal flood mitigation plan using analytic hierarchy process. J. KOSHAM 2009, 9, 117-126.

29. Haque, C.E.; Blair, D. Vulnerability to Tropical Cyclones: Evidence from the April 1991 Cyclone in Coastal Bangladesh; John Wiley and Sons: Malden, MA, USA, 1991.

30. National Emergency Management Agency. Annals of disasters 2007; National Emergency Management Agency: Seoul, Korea, 2008.

31. Han, B. A study on Cause Analysis and Counterplan for Urban Flood Due to the Extreme Rainfall. Master's Thesis, University of Seoul, Seoul, Korea, 2011.

32. Lee, S. History of river improvement. River Cult. 2011, 7, 12-16.

(C) 2015 by the authors; licensee MDPI, Basel, Switzerland. This article is an open access article distributed under the terms and conditions of the Creative Commons by Attribution (CC-BY) license (http:/ / creativecommons.org/licenses/by/4.0/). 